\title{
Towards equality: joining forces with arts and culture in the struggle for change in migration societies
}

\author{
Wiebke Sievers(10
}

\author{
Correspondence: wiebke.sievers@ \\ oeaw.ac.at \\ Austrian Academy of Sciences, \\ Postgasse 7/4/2, 1010 Vienna, \\ Austria
}

\begin{abstract}
There is a tendency in migration research to view artistic and cultural practices of immigrants and their descendants as well as the research of such practices as less relevant for our understanding of migration. This explains why it has long been a neglected area of research in the social sciences, as Marco Martiniello explains in his contribution to this volume. The present article argues that drawing such boundaries prevents us from seeing the joint aims not only of migration research in the social sciences and the humanities, but also of this research and the arts. It prevents us from seeing the potential of joining forces in our struggle for change towards more equal societies. The article explains how social science research and artistic and cultural practices can be regarded as two supplementary methods of struggling for equality that together have a greater chance of reaching this aim. Artistic and cultural practices contribute perspectives for changing community narratives to this process of change. These are essential for political and social change as they are championed in the social sciences.
\end{abstract}

Keywords: Yahya Hassan, Equality, Imagined communities, Immigration

\section{Towards equality}

There is a line of thought that regards the artistic and cultural activities of migrants and their descendants as providing us with personal insight into migration processes and the lives of migrants in their host countries (Vlasta, 2016). The underlying assumption of such interpretations is that those who have not had these experiences will realise that migrants are not what they are portrayed to be by right-wing populist parties and the media, and that they therefore will begin to view such ascriptions critically and become more empathetic and tolerant (Nussbaum, 2010, pp. 107-108; Roche, 2004, p. 22). This article does not claim that artistic and cultural products cannot have such effects. ${ }^{1}$ Rather, it claims that they have even more potential. They do not just tell us about migration and migrant communities, but they actively intervene in the debates about societies that have increasingly been characterized by migration without

\footnotetext{
${ }^{1}$ Marco Martiniello's contribution to this special issue is an excellent example of the importance of such approaches.
}

() The Author(s). 2021 Open Access This article is licensed under a Creative Commons Attribution 4.0 International License, which permits use, sharing, adaptation, distribution and reproduction in any medium or format, as long as you give appropriate credit to the original author(s) and the source, provide a link to the Creative Commons licence, and indicate if changes were made. The images or other third party material in this article are included in the article's Creative Commons licence, unless indicated otherwise in a credit line to the material. If material is not included in the article's Creative Commons licence and your intended use is not permitted by statutory regulation or exceeds the permitted use, you will need to obtain permission directly from the copyright holder. To view a copy of this licence, visit http://creativecommons.org/licenses/by/4.0/. 
having adapted to this new reality. ${ }^{2}$ What the artists demand is not just tolerance or empathy, but equality regardless of origin, religion, and ethnicity.

It may seem strange that this is still necessary more than 70 years after the Universal Declaration of Human Rights and the European Convention of Human Rights have been adopted. However, their adoption cannot be regarded as installing a new regime. In fact, the declaration and the convention were nothing more than utopian visions at the time. Achieving these utopias is an ongoing process, as Samuel Moyn has rightly pointed out: ' $[\mathrm{H}]$ uman rights are not so much an inheritance to preserve as an invention to remake $[\ldots]$ if their program is to be vital and relevant in what is already a very different world than the one into which it came so recently' (Moyn, 2010, p. 9). The artistic and cultural activities of migrants and their descendants can be regarded as such re-inventions of human rights in societies that are increasingly characterized by migration. They take human rights as an inspiration to rethink the world and reimagine communities in a way that reflects this change. Of course, they are not the only ones doing that. They are part of a larger impetus for change that is also supported by many migration researchers when they rethink citizenship (Bauböck, 1994) or demand that states live up to the promises of liberal pluralism they make in their constitutions (Foroutan, 2019), to give just a few examples. However, artistic and cultural activities have their own means of bringing about change. They are particularly well suited for reimagining our communities in new narratives that move beyond the idea of homogeneous national identities and cultures. That arts and culture were essential in inventing these communities in the nineteenth century, as explained by Anderson (1991, pp. 2426), implies that they have the potential to effectuate such a change again. By working towards new community narratives based on the equality of all people, they can counter right-wing populists who aim to reinstall narratives of national homogeneity and thus cement the unequal treatment of those they regard as migrants.

Migration researchers are not necessarily aware that artists and scholars in the humanities share the aim of moving towards equality. This has to do with disciplinary boundaries that are not easily overcome, but also with the fact that the artistic and cultural activities of migrants are not automatically understood as claims for equality. In fact, sometimes they are interpreted to do the exact opposite, namely confirm the views of right-wing populists, as the following discussion of Yahya Hassan's poetry will show. Such contradictory readings are possible because the artists work in the twilight of an historic interregnum in which "the old is dying and the new cannot be born"' (Mercer, 1994: 2, citing Gramsci). If we read migrants' literary works in the narrative frameworks of homogeneous national identities, we come to a different conclusion regarding the intention of their words than when we read them as creating a new narrative framework. In other words, we need to follow the artists on a journey during which they teach us a new way of understanding the world around us. This means leaving behind the old narratives, which is not an easy process because they are deeply ingrained in us. They structure our understanding of the world without our being aware of them

${ }^{2}$ For this understanding of art I draw on Bourdieu's argument that the relative autonomy of art and literature has led to artists gaining a say in public debates as intellectuals (Bourdieu, 1996). That this has been an important factor for migrants and their descendants becoming writers in many different contexts is illustrated in the overviews gathered in the volume Immigrant and Ethnic-Minority Writers since 1945 (Sievers \& Vlasta, 2018). 
(Nünning, 2013). However, embarking on this journey is rewarding because it will allow us to see our world in a new light.

In the following, I will take you on such a journey using Yahya Hassan's poetry as an example. The primary aim of this endeavour is to provide insight into the reading of his works in the old narrative frameworks of homogeneous national identities and to present methodological means that allow us to move beyond such readings towards identifying the new narrative of identity created in the text. However, this is not the only comparative aspect of this article. The larger aim is to highlight the comparable aims of artists, migration researchers in the social sciences, and migration researchers in the humanities concerning equality. It is important that we understand each other better so that we can join forces in making our results publicly heard, an aspect that definitely needs more attention as Steven Vertovec (2020) points out.

\section{Yahya Hassan: beyond limiting community narratives}

The poet Yahya Hassan was born into a Palestinian family in Aarhus, Denmark, in 1995, and died there in 2020. Hassan became known to a wide readership far beyond Denmark in 2013 when the reputable Danish publishing house Gyldendal launched his poetry collection entitled YAHYA HASSAN. ${ }^{3}$ The book is a poetic examination of the author's life until the point of publication. Amongst others, it deals with paternal violence in his childhood, his feelings of not belonging in the kindergarten and at school, his turn to criminality and drugs in adolescence, his experiences of violence in state institutions, his turn from being a victim to being a perpetrator of violence, the specific situation of Palestinian exile, and the hypocrisy of his violent and criminal male family members who claim to be religious Muslims. The book is one of the most popular poetry collections ever published in Denmark, with more than 100,000 copies being sold in a country where an edition of 400 is normal for poetry volumes (Hoffmann, 2018, p. 142). The interview the author gave in advance of the publication - entitled 'I'm fucking mad at my parents' generation' (Omar, 2013) - has become one of the most frequently shared texts in Danish online history (Gokieli, 2015, p. 210). Hassan also received massive attention abroad, in newspapers such as The Guardian, New York Times, Wall Street Journal, Spiegel and Frankfurter Allgemeine (Hoffmann, 2018, p. 151).

The main reason for this outstanding attention was the controversial discussion concerning migrants, particularly Muslims, sparked by the book and by the interview preceding its publication. This discussion was not new: it started in Europe with the response to Salman Rushdie's The Satanic Verses in 1988, became prominent after 9/ 11, and was fanned by the Mohammed caricatures in the Danish daily newspaper Jyllands-Posten in 2005 (Rytter \& Pedersen, 2013, pp. 2309-2310). Many commentators welcomed Hassan's book, arguing that finally an author provided a realistic insight into the Muslim community, a step long prevented by political correctness they argued. Among these were many right-wing voices who felt confirmed in their views of Muslims as lazy and criminal, but also left-wing voices who claimed that the volume exposed the failure of the Danish authorities. Both were opposed by commentators, particularly of Muslim origin, who felt offended by the poems. The most extreme

${ }^{3}$ Not only the title, but the whole book is written in capitals. This is a stylistic device, a "shouting" and "loud" typography' (Hoffmann, 2018, p. 142), 'a visual outcry of anger, a proclamation of protest' (Gokieli, 2015, p. 217). I therefore also use capitals when citing the book. 
reactions were death threats and attacks on the author. Others, such as the Swedish poet Athena Farrokhzad, accused Hassan of providing right-wing populists and their supporters with further arguments against migrants and particularly against Muslims (for an overview of the debate see Hoffmann, 2018, pp. 142-144; Sochańska, 2017).

Even this short insight into the debate shows that most commentators regarded the author and his work as representative of a community. This is a typical way of reading minority art, especially when only a few people from a specific ethnic or religious group have become visible as artists (Mercer, 1994). This has been the case in Denmark, where literature written by migrants and their descendants was scarce before Hassan's book was published (Frank, 2013). Research has not freed Hassan from this 'burden of representation', as Kobena Mercer called it. Even though the scholars who have discussed his book are critical of such representational interpretations, they nevertheless focus on markers of ethnic and religious difference in his work, such as his positioning as an 'immigrant writer' (Gokieli, 2015) as well as the role of Islam (Hoffmann, 2018) and of 'perkerdansk', a Danish speech variety mainly used by migrants and their descendants, in his poetry.

I argue that YAHYA HASSAN does not primarily deal with a migrant community or a religious group. On the contrary, the book is Yahya Hassan's poetic autobiography, as he explicitly states in the last poem: 'HERE IS MY STORY!' (Hassan, 2013, p. 98). It is a claim for individuality, personal liberty, and freedom of expression of an individual primarily regarded as part of a group both by his family and by those Danes who do not perceive him as Danish. These human rights are constitutionally guaranteed to him just as to any Danish citizen, but the physical and symbolic violence he had had to endure from his early childhood onwards shows that this guarantee was nothing more than an empty promise. Moreover, making use of his right of speech does not mean the same as it does for other writers in Denmark, as the fierce discussion of his book illustrates. Hassan was aware of this inequality when writing his book. In the last poem, he explicitly points his readers to his stigmatisation as an author of immigrant origin: 'ME I JUST MAKE A CLICHÉ/ SO THERE/ A CLICHÉ/ FOR YOUR LITTLE CLICHÉ HEAD' (Hassan, 2013, p. 107). ${ }^{4}$ The phrase MIG JEG (Me I), typical for the Danish variant spoken by Arabic youths, is used more than 150 times in this last poem of the volume (Grydehøj, 2020, p. 157). This dual reference to the self constitutes a poetic device to express both the claim for individuality and, as rightly suggested by Grydehøj, 'the split of the poetic voice into an object (me) and a subject (I) [ ...] alluding to the construction of the immigrant voice from both internal and external positions' (Grydehøj, 2020, p. 157).

How did I reach the interpretation that the volume is a claim for individuality and freedom? Of course, the most important method is a close reading of the literary work, a long-established method in literary studies. However, the close reading of an author of immigrant origin demands further skills. The interpreter needs to move beyond othering the author, beyond regarding her/him first as a descendant of immigrants and as a Muslim, without however ignoring the fact that $\mathrm{s} /$ he is a descendant of immigrants and a Muslim. Emmanuel Lévinas has suggested that the best method of avoiding the objectification of the other is to approach her/him in conversation:

${ }^{4}$ I here use the English translation by Grydehøj (Grydehøj, 2020, p. 160). If not mentioned otherwise, all translations are mine. 
To approach the Other in conversation is to welcome his expression, in which at each instant he overflows the idea a thought would carry away from it. [...] But this also means: to be taught. The relation with the Other, or Conversation, is a non-allergic relation, an ethical relation; but inasmuch as it is welcomed this conversation is a teaching [enseignement] (Levinas, 1961, p. 51).

Researching migration through the artistic and cultural practices of migrants and their descendants is ideal for approaching the other in conversation because it is the migrant who speaks first through a poem, a theatre play, a song, or a film. The researcher responds. This response should not start out from whom we think the other is, but from what s/he has to say, what s/he can teach us. In line with this, the primary objective is not to understand the other, but to change our understanding of the world through confrontation with the other. This process of change has implications for the way in which we conceive not only migration and migrants, but also community and social justice.

In concrete terms, this means that we should not start our close reading with elements that confirm our preconceptions, but choose a starting point that surprises us, that challenges our preconceived ideas. There are many such starting points in any literary text - in fact as many as there are readers. I will here present the one that was decisive for my reading of the poetry collection YAHYA HASSAN as a claim to individuality and equality: his explicit reference to the Norwegian writer Karl Ove Knausgård in the two poems 'LEGAL NIGHTWORK' and 'ARRESTED' (Hassan, 2013, pp. 49, 53). The first deals with a period in the poet's life in which he helped a cousin deliver books at night, with the reward being the returned books, among these 'USELESS CRIME NOVELS AND ONE KNAUSGÅRD' (Hassan, 2013, p. 49), an explicit hint at his literary interests. In the second, he clarifies that the one Knausgard is a volume of his world-famous autobiographical novel Min kamp (My Struggle) published between 2009 and 2011 (Hassan, 2013, p. 53).

The novel may in many respects be regarded as an inspiration for Yahya Hassan's volume of poetry. My Struggle is a detailed account of the author's life from his early childhood to the writing of these books and their publication. However, the point is not to narrate a life, as Arnaud Schmitt and Stefan Kjerkegaard have rightly suggested, but to narrate a self (Schmitt \& Kjerkegaard, 2016, p. 555). Toril Moi has interpreted this narrative search for a self as being essentially about overcoming alienation by breaking with the image others have of him as well as with their internalised judgements. The result is freedom:

His masterpiece finished, he is free; now, finally, he can be himself. Here we should remember that being oneself is not to claim a specific identity. On the contrary, it means finally to be able to escape the split between self and identity, to escape alienation and be able to engage completely in one's actions, to live without internalising the judgments of others (Moi, 2018b).

Knausgård's struggle for freedom is ruthless (Moi, 2018a). It takes no account of the feelings of family and friends who might be hurt by his openness about himself and his thoughts about them. This ruthlessness has sparked enormous discussion in Norway 
and beyond, but unlike in the case of Hassan, it has not been read as providing us with realistic insight into the Norwegian community. Moreover, it has not kept reviewers and scholars from reading the work as ground-breaking in literary terms.

Yahya Hassan adopts Knausgård's idea of freeing the self from the image of others, but in his case, this is a more complex endeavour since it does not only concern his family and friends, but all those who infringe upon his individual rights by imposing a community identity on him. This becomes obvious in the first poem entitled 'CHIL DHOOD'. The poem provides us with insight into the physical and symbolic violence that Hassan has experienced since his early childhood (Hassan, 2013, p. 3). It starts with a harrowing description of five children waiting in a row for their father to beat them. We see their tears and how they wet themselves out of fear and pain, we hear how the cane strikes their hands or, if they withdraw these, other parts of their bodies: 'A BLOW A CRY A NUMBER 30 OR 40 OR SOMETIMES 50'.

The poem compares this physical violence with other instances of violence present in their young lives. The first is the violence in the Gaza strip shown on Al Jazeera while the children are beaten by their father. The images of 'HYPERACTIVE BULLDOZERS AND ANGRY BODYPARTS' are interpreted from the family's Palestinian perspective taken over by the young boy: 'IF THE ZIONIST DOES NOT RECOGNIZE OUR EXISTENCE/IF WE EXIST AT ALL'. The word OUR in the first sentence refers to the Palestinian community identity imposed on him by his family in Denmark and in refugee camps in Lebanon where he spends his holidays. The WE in the second sentence is no longer just a reference to this group, but expresses what this inheritance means for the children. They grow up with a community identity that roots them in non-existence. Unlike other imagined communities, the Palestinians do not have a founding myth that explains how they came into existence. Rather, their community narrative starts with a catastrophe, their expulsion from Palestine in 1948, an event they call al-Nakba. This myth of 'un-becoming', as Anja Kublitz calls it, structures Palestinian lives up to their present in Denmark, also because they feel that they will never be accepted as Danish: 'Whereas al-Nakba, the figure of un-becoming, is reproduced on the level of the individual as the disintegration of the subject [ ...], what Palestinians in Denmark simultaneously experience is that the most obvious alternative path towards becoming, namely becoming Danish, is blocked' (Kublitz, 2015, p. 244).

The poem CHILDHOOD describes how this feeling of non-existence is transferred to the children of Palestinian refugees born in Denmark both through the violence of the father and through the Palestinian community narrative. It ends by showing that such narratives can be equally destructive for the development of an individual identity as are the blows of the father. The last verses highlight how both institutions most influential in the early development of a child into an individual - family and school - impose community narratives that annihilate the existence of Hassan and his siblings as multilingual individuals. These institutions demand that they ignore one half of their personality and divide their selves into being one person at school - 'AT SCHOOL WE ARE NOT ALLOWED TO SPEAK ARABIC'- and another at home: 'AT HOME WE ARE NOT ALLOWED TO SPEAK DANISH'. The last sentence describes the effect of these narratives in the same terms as the blows of the father: 'A BLOW A CRY A NUMBER'. The symbolic narratives that force the children to align with either the one or the other 
community breach their right to individuality and equality just as much as the blows of the father do. ${ }^{5}$ The narratives do not make room for these individuals.

Hassan presents his criticism of violent community narratives in a poetic style that questions the idea of homogeneity underlying these narratives. This is less obvious in the printed texts than in the public performances of his work (for excerpts from a performance see Wagner, 2014). Thomas Hoffmann points out that many critics have noted the closeness of Hassan's reading style to Qur'anic recitation. As an integral part of Islamic ritual praxis, this tradition was known to the author from early childhood. Even though religion meant little to him, Islamic recitation has been an important source of inspiration - he even described it as his religion. He listened to Qur'anic recitation as others listen to music and even recorded himself reciting a surah of the Qur'an (Hoffmann, 2018, pp. 148-149). ${ }^{6}$ Hoffmann himself, however, is not convinced that this tradition has been an inspiration for Hassan's poetic style: 'I have not yet come across any Arabic-Danish-speaking Muslims who have characterised Hassan's reading style as Qur'anic in terms of style' (Hoffmann, 2018, p. 148). He believes that the roots of this style lie in European and Danish poetry performances (Hoffmann, 2018, p. 149). I believe that Hassan draws on both traditions. He intentionally mixes Qur'anic recitation and European and Danish poetry performances so that they become unrecognizable as different individual traditions. What emerges is a new poetic form that allows Hassan to express his self. In addition, this new form illustrates that these traditions are not mutually exclusive, as claimed in homogeneous narratives of national identities and cultures. They can easily be merged into a new narrative of individual identity. Why should the same not hold true for narratives of community?

\section{Towards joining forces for change in migration societies}

The poetry volume YAHYA HASSAN is a claim for equality of an individual whose rights were infringed upon not only by his violent father, but also by community narratives that do not make room for his individual existence. At the same time, the author creates a new poetic form that merges elements from these community narratives. As such, the volume may serve as a model for reimagining European communities in narratives that no longer regard these and other differences within Europe as mutually exclusive, but merge them into a new vision for Europe. Both Bauböck and Foroutan have stressed the importance of such a narrative change for political and social change. To cite Bauböck: 'How migration changes citizenship depends to a large extent on how states and their citizens perceive migrants' (Bauböck, 2002, p. 2). For such perceptions to change, our understanding of societies needs to change, as Willem Schinkel explains: 'It is fruitful to focus on the imaginary character of "society." That is not to say that the existence of society is fiction, but that society exists as fiction. A society is a creative fiction, a map that claims to be a territory' (Schinkel, 2017, p. 222). If 'society exists as fiction', as Willem Schinkel put it, then turning to literature and arts for imagining new narratives of society is a logical step forward in

${ }^{5}$ For an analysis of the violent character of community narratives from a social-science perspective, see Schinkel, 2017.

${ }^{6}$ For the recording see Hassan, 2014. 
reimagining societies. In other words, artists and migration researchers in the humanities and the social sciences are working on a process of change that needs both sides to be successful. Why not join forces in this process to finally make this change happen? Ideally, this would mean more interdisciplinary work that combines these complementary perspectives in joint projects. However, a first step towards this ideal would be to regard the position of the respective other as relevant for installing equality in migration societies.

\section{Acknowledgements}

I would like to thank my student Inés Noé for raising my interest in the writer Yahya Hassan with her stimulating analysis of Hassan's reception in the German context. I am also indebted to two anonymous reviewers whose detailed comments greatly helped me to nuance and clarify my argument. Last but not least, I am grateful to Hanneke Friedl for her careful linguistic editing of the text. All remaining errors and inconsistencies are, of course, mine.

Author's contributions

The author read and approved the final manuscript.

Funding

Not applicable.

Availability of data and materials

Not applicable.

\section{Declarations}

\section{Competing interests}

The author declares that she has no competing interests.

Received: 24 February 2021 Accepted: 16 June 2021

Published online: 15 September 2021

\section{References}

Anderson, B. (1991). Imagined communities: Reflections on the origin and the spread of nationalism (revised 7th ed.). Verso. Bauböck, R. (1994). Transnational citizenship: Membership and rights in international migration. Elgar.

Bauböck, R. (2002). How migration transforms citizenship: International, multinational and transnational perspectives. IWE working paper series, 24. Retrieved from https://eif.univie.ac.at/downloads/workingpapers/IWE-Papers/WP24.pdf.

Bourdieu, P. (1996). The rules of art: Genesis and structure of the literary field (S. Emanuel, Trans.). Polity Press.

Foroutan, N. (2019). Die postmigrantische Gesellschaft: Ein Versprechen der pluralen Demokratie. Transcript.

Frank, S. (2013). Is there or is there not a literature of migration in Denmark? In W. Behschnitt, S. D. Mul, \& L. Minnaard (Eds.), Literature, language, and multiculturalism in Scandinavia and the low countries, (pp. 197-223). Brill/Rodopi.

Gokieli, N. (2015). The iconicity of an 'immigrant writer': Jonas Hassen Khemiri and Yahya Hassan. Akademisk Kvarter, 10, 208-221.

Grydehøj, A. (2020). New Scandinavians, new narratives. In A. Lindskog, \& J. Stougaard-Nielsen (Eds.), Introduction to Nordic cultures, (pp. 146-161). UCL Press. https://doi.org/10.2307/j.ctv13xprms.16.

Hassan, Y. (2013). Yahya Hassan: Digte (e-book ed.). Gyldendal.

Hassan, Y. (2014). Surat Alahzab 1-22. Retrieved from https://www.youtube.com/watch?v=ZYtciBIKLME.

Hoffmann, T. (2018). "ALLAH IS IGNORANCE": An essay on the poetic praxis of Yahya Hassan and the Critique of Liberal Islam. In N. V. Vinding, E. Račius, \& J. Thielmann (Eds.), Exploring the multitude of Muslims in Europe: Essays in honour of Jørgen S. Nielsen, (pp. 141-153). Brill.

Kublitz, A. (2015). The ongoing catastrophe: Erosion of life in the Danish camps. Journal of Refugee Studies, 29(2), 229-249. Levinas, E. (1961). Totality and infinity. Duquesne University Press.

Mercer, K. (1994). Welcome to the Jungle: New Positions in Black Cultural Studies. New York: Routledge.

Moi, T. (2018a). Knausgaard's ruthless freedom. Public Books Retrieved from https://www.publicbooks.org/knausgaardsruthless-freedom/.

Moi, T. (2018b). Shame and openness: How to read Karl Ove Knausgaard. ABC Religion \& Ethics Retrieved from https://www.a bc.net.au/religion/how-to-read-karl-ove-knausgaard/10547858

Moyn, S. (2010). The last utopia: Human rights in history. Belknap Press of Harvard UP.

Nünning, A. (2013). Wie Erzählungen Kulturen erzeugen: Prämissen, Konzepte und Perspektiven für eine kulturwissenschaftliche Narratologie. In A. Strohmaier (Ed.), Kultur - Wissen - Narration: Perspektiven transdisziplinärer Erzählforschung, (pp. 15-53). Transcript.

Nussbaum, M. C. (2010). Not for profit: Why democracy needs the humanities. Princeton University Press.

Omar, T. (2013). Jeg er fucking vred på mine forældres generation. Politiken Retrieved from https://politiken.dk/debat/art558922 6/\%C2\%BBJeg-er-fucking-vred-p\%C3\%A5-mine-for\%C3\%A6ldres-generation\%C2\%AB.

Roche, M. W. (2004). Why literature matters in the 21st century. Yale University Press. https://doi.org/10.12987/yale/97803001 04493.001.0001.

Rytter, M., \& Pedersen, M. H. (2013). A decade of suspicion: Islam and Muslims in Denmark after 9/11. Ethnic and Racial Studies, 37(13), 2303-2321. https://doi.org/10.1080/01419870.2013.821148. 
Schinkel, W. (2017). Imagined societies: A critique of immigrant integration in Western Europe. Cambridge University Press. https://doi.org/10.1017/9781316424230.

Schmitt, A., \& Kjerkegaard, S. (2016). Karl Ove Knausgaard's My Struggle: A real life in a Novel. a/b: Auto/Biography Studies, 31(3), 553-579. https://doi.org/10.1080/08989575.2016.1184543.

Sievers, W., \& Vlasta, S. (Eds.) (2018). Immigrant and ethnic-minority writers since 1945: Fourteen national contexts in Europe and beyond. Brill/Rodopi. https://doi.org/10.1163/9789004363243.

Sochańska, B. (2017). Rhythm is essential. Retrieved from https://www.danishculture.com/theme/rhytm-is-essential/.

Vertovec, S. (2020). Two cheers for migration studies. Comparative Migration Studies, 8(38). https://doi.org/10.1186/s40878-02000195-0.

Vlasta, S. (2016). Contemporary migration literature in German and English. A comparative study. Brill/Rodopi. https://doi.org/1 $0.1163 / 9789004306004$.

Wagner, M.C. (2014). Yahya Hassan: poems of rage. Retrieved from https://channel.louisiana.dk/video/yahya-hassan-poems-rage

\section{Publisher's Note}

Springer Nature remains neutral with regard to jurisdictional claims in published maps and institutional affiliations.

Submit your manuscript to a SpringerOpen ${ }^{\circ}$ journal and benefit from:

- Convenient online submission

- Rigorous peer review

- Open access: articles freely available online

- High visibility within the field

- Retaining the copyright to your article

Submit your next manuscript at $>$ springeropen.com 